\title{
The Role of Advertisements in JUUL Consumption: Analyzing the Connections between Different Stimuli on Advertisements and Teenage Vaping
}

\author{
Natalie Willis ${ }^{1}$ and Melanie Mindicino ${ }^{1}$ \\ ${ }^{1}$ David Posnack School, Davie, FL, USA
}

\section{ABSTRACT}

In the last three years, JUUL Company has gained popularity through the media because of its party-themed advertisements and subsequently, its rise in teen vape consumption. While other studies have researched the increase of vaping in the previous years, this paper will draw connections between different stimuli on the JUUL advertisements and its effects on teenage vaping. In order to examine these connections, the author conducted a study to further analyze particular advertising practices used by the JUUL Company to attract the younger generations to their product; specifically, the study has two components that gather quantitative and qualitative data. For the first element of the study, the author created a survey that tests the effectiveness of different stimuli on the advertisements and distributed it to participants ranging from thirty-three years old to eighteen years old. The resulting age gap allowed the author to gather information from subjects with different life experiences and maturity. The findings of this section concluded that the participants within the ages of eighteen and twenty-two are influenced by their involvement in a social media echo-chamber; therefore, the younger generations do not even recognize their association with the echo-chamber but continue to fall into trend cycles since the trends, such as vaping, consume their internet feed. Overall, both adults and teens were able to acknowledge the strong presence of 'Juuling' in their communities and the majority labeled the JUUL posters as "party-like". In the second element of the study, the author conducted group experiments with high school students ranging from fourteen years old to eighteen years of age. The findings of this section proved herd mentality and psychological reactance as the participants began to copy each other's behavior and became attracted to the advertisements that were presented as 'unattainable'. This study validates the effectiveness of the stimuli on advertisements when analyzing its connections to teenage vaping. Therefore, as a future solution, corporate lobbying in government for JUUL must be further restricted and minimal so teenagers will not be as exposed to JUUL's marketing and in return, there will be a decrease in death rates caused by vaping.

\section{Introduction}

The term "e-cigarettes," or electronic cigarettes, has been widely publicized throughout modern society but has specifically gained the attention of high school students. As different e-cigarette companies begin to fascinate consumers, vaping devices have invoked a wave of ultramodern smoking. Companies initially developed electronic cigarettes as a rehabilitation option for tobacco addicts to halt an increase in cigarette addiction. A Chinese pharmacist, Hon Lik, invented one of the first devices to assist smoking adults because his father had died from lung cancer. Although Hon Lik entered this business with honorable intentions, health departments in the United Kingdom questioned whether the promotion of these electronic cigarettes would glamorize smoking. Nevertheless, the vaping devices succeeded in the industry, and almost immediately the United States began selling this new product in 2007 (Fehre, 2014). It was not too long before competing brands such as JUUL, Kangertech, and NJOY appeared. In the last three years, JUUL has gained a majority market share with consumers because of its party-themed advertisements, which subsequently 
have been blamed for an increase in youth consumption of the JUUL brand; furthermore, their attractive USB-like appearance allows the device to be used clandestinely.

Some studies that have explored the rise in teen vaping have concluded that teen immaturity and the rush a teenager may experience when sneaking the unobtrusive device have contributed to increased use. This study will focus on the gap in marketing and advertising practices that have influenced teenage habits concerning increased vape pen use. The growth of vaping in the past decade indicates that other factors, besides maturity levels and an addictive "rush," have caused a huge increase in profit for the JUUL Company. Consequently, the researcher will review previous JUUL advertisements and investigate techniques used that may have played a role in its evolution. The researcher will analyze whether or not modern companies use insidious practices such as color-connection-focused advertising, psychological reactance, and high school peer pressure to better advertise their addictive products to young consumers.

\section{Literature Review}

To analyze the marketing strategies of the e-cigarette companies, it is important to examine past research and conducted studies. Most consumers believe that the designs and colors that are used for branding enhance advertisements for e-cigarette companies. However, the companies employ branding experts to reach consumers on a psychological and subconscious level. The shades of colors used in the commercials reflect the type of consumers the company wants to attract, along with the reputation that the companies want to portray. Therefore, brands strategically choose colors to present themselves with a desirable connotation (Shlack \& Albright, 2007 ). Although, a study conducted in 2007 by the scientific journal, Neuron, claimed, “...the associative learning of visual information develops during early stages of visual processing as a key mechanism for quick decision-making and survival" (Shlack \& Albright, 2007 ). This reinforces the idea that the color pairs that are advertised, appeal to the consumers who have memories associating with the colors. As a result of these pairings, people tend to become loyal consumers and buy products that display the colors that link to their memories. The specific colors that are chosen for branding allow the producerconsumer relationship to develop and strengthen through their color-connections. As cited in the scientific journal, Open Journal of Social Sciences, it only takes seconds for a consumer to be swayed by the colors of a brand's advertising and develop an individual opinion on the company before even becoming knowledgeable on general information (Cunningham, 2017).

Further research analyzes the effects of the saturation levels on a logo and the consumer's ability to process the wavelengths of color. The research study directed by the Academy of Marketing Science, concluded that the colors red, yellow, and orange trigger excitement and stimulation in the brain, while the color blue evokes feelings of serenity and reliance (Aslam, 2006). Hence most restaurants embrace the color blue in their designs since the relaxing ambiance would result in their customers remaining longer while ordering more meals. Whereas, in fast-food chains, according to the company, Karen Haller Colour and Design Consultancy, the colors red and yellow are used to cause the sensations of speed, excitement, and hunger (Haller, 2011). In return, these emotions lead to consumers frequently eating at these food-chains and creating habitual patterns.

The JUUL advertisements specifically reflect the culmination of these studies and contain the aforementioned colors red, yellow, and orange. As previously demonstrated, these colors have the physiological effect of giving consumers brief feelings of speed and excitement and symbolize the advertising practices of JUUL. Additionally, JUUL advertisements display different shades of blue which has been proven to invoke the feeling of reliance (Aslam, 2006). Accordingly, consumers are more likely to become loyal and continue buying their products. As discussed by the news editorial, Sciencing, bright colors gain the attention of younger brains because of the techniques used to help them identify the colors (Pancare, 2018). For instance, the color yellow can be associated with the sun, just as the color green can relate to grass. It may be concluded that these intentional color choices in the JUUL posters may appeal to younger audiences. Similarly, the JUUL commercials on television have a pink and blue hue of the color 
cast on the screen. The objective of the color blue is shown to persuade consumers to trust the reliability of the company and product, while the color pink is known to represent unconditional love and nurturing feelings (Cherry, 2019). The two main colors in the JUUL commercial collaborate to give consumers both feelings of nurturing and assurance which strengthen the trust of the consumer in the brand.

Another marketing strategy used by prosperous companies is reverse psychology within their advertising. A study conducted about reverse psychology by the Department of Managing and Marketing in The Hong Kong Polytechnic University states, "This technique has been applied by marketers in advertising in which a negative message or tagline (e.g., "you don't buy the product) is used to motivate consumers to make a purchase" (Leung \& Chan, 2018). By making the consumer feel restricted and as if they do not have the freedom of choice to buy the product, the immediate response of the consumer is to purchase the product. The results of the study conducted at The Hong Kong Polytechnic University supports the conclusion that reverse psychology in advertising draws more interest to the product even though most subjects were uncomfortable with the negative message displayed in the advertisement (Leung \& Chan, 2018). This poses as a prime example of psychological reactance; the theory that people will desire to regain and be in control of their freedom if their freedom is eliminated or reduced (Brehm,1966). For example, "The Real Cost" campaign, established in 2014, promotes and produces advertisements displaying the consequences of smoking cigarettes and vaping e-cigarettes (The Real Cost Campaign, 2019 ). Instead of data showing a decrease in tobacco usage as a result of the launch of the campaign, the Morbidity and Mortality Weekly Report, a medicine-related journal published by the Centers for Disease Control and Prevention, presents a study that concludes, "Driven by an increase in e-cigarette use, current tobacco product use significantly increased among high school and middle school students during 2017-2018, erasing the decline in tobacco product use among youths that occurred in previous years" (Gentzke, et al., 2019).

The study also claims that in 2018, 4.04 million high school students and 840,000 middle school students were using tobacco products (Gentzke, et al., 2019). Therefore, this supports the theory of psychological reactance by showing that once the dangers of cigarette and e-cigarette usage were advertised throughout social media platforms and television, there was an increase in consumers rather than a decline in the company's profits. The JUUL company also established a campaign in 2018 named, "What Parents Need to Know About JUUL", which warns viewers that JUUL is specifically for adults and to avoid vaping if the consumer is not an addictive smoker (Juul Labs Launches Advertising Campaign Aimed At Raising Awareness And Combating Underage Use, 2018). In comparison to "The Real Cost" campaign, both movements encouraged a restriction, whether it be a restriction of age or the usage of a product, and as a result, caused an increase in consumers because people becoming motivated to regain their sense of freedom through the theory of psychological reactance.

The way the human-eye influences a person's behavior is also just an advantage used by widespread companies to gain sales, similarly to how successful franchises use herd mentality to increase their popularity. For instance, when a consumer considers purchasing an item, they tend to look for recommendations from other customers and subconsciously, fall into the human tendency to follow the crowd. As explained in a study conducted at the University of Exter, led by Dr. Colin Torney, "The result is that groups evolve to be unresponsive to changes in their environment and spend too much time copying one another, and not making their own decisions" (Herd mentality: Are we programmed to make bad decisions? 2019). Since the consumers are occupied mimicking each other, companies can easily gain attention to their product merely through their reliance on herd mentality. Especially in this technological era, social media plays a role in gaining the attention of consumers through uploaded videos or pictures related to the product. A study published in the Journal of Medical Internet Research considered the impact of the social media platform, YouTube, and the number of views of e-cigarette related videos. The research stated, Videos were posted by approximately 10,000 unique YouTube accounts, viewed more than 100 million times, rated over 380,000 times, and commented on more than 280,000 times... The number of e-cigarette-related YouTube videos was projected to exceed 65,000 by the end of 2014, with approximately 190 million views (Huang, Kornfield, \& Emery, 2016). 
As a result of the large number of views gained from e-cigarettes on YouTube, it has become a trend with the younger generations to vape from a JUUL and uploads it on social media. The devices sold from the JUUL company have become popular among younger generations to a point that a specific verb has been created, about the company's name. Young teens are now referring to vaping as "Juuling," which heightens the attractiveness of this act and shows the popularity around JUUL in response to the trend created in the media. About a previously discussed study led by Dr. Colin Torney, users of the social media platforms now copy each other by participating in the new trend of 'Juuling' and are unable to make their own decisions. A study published in BM Journals claims, "Approximately half of the posts featured content related to youth (55\%) or lifestyle (57\%). Youth-related content or lifestyle appeals were also notably present within promotional posts and nicotine and addiction-related posts, respectively. Nicotine and addiction-related posts featured memes, hashtags (eg, \#nichead, \#juulbuzz) and tag lines (eg, 'more flavor, more buzz')" (Czaplicki, et al., 2019). The media has become ingrained in the younger generations through comedy and the importance of the latest-thing and for that reason, all content uploaded is immediately consumed by the youth and transformed into a trend that all users feel obligated to participate in. Under these circumstances, companies do not have to spend their resources advertising to the youth as they all follow each other by adopting the trends on social media and in this instance, posting videos of themselves vaping.

Therefore, this study's research will highlight whether the JUUL companies' marketing strategies such as colorconnection, psychological reactance, and social media involvement cause teenage engagement and will analyze the effectiveness of these techniques.

\section{Hypothesis}

The researcher hypothesizes that younger, developing minds will be more attracted to advertisements with pink and blue. Similarly, young people are attracted to the pink and blue hues shown in the JUUL commercials. Adolescents will also be intrigued by advertisements that demonstrate appealing drawings or pictures of youthful women. However, if an advertisement is introduced to them as unattainable, despite resembling the colors in the JUUL commercials, the subjects will be fascinated with it as a result of psychological reactance. Then, when the subjects are asked to discuss a topic in a group setting, their opinions will change depending on the group's attitude towards the topic because of the tendency to follow group mentality.

\section{Methodology \#1}

To prove the hypothesis, this study will begin to experiment with the impacts of color-connections and group mentality on students, compared to adults.

\section{Participants}

152 subjects were participating in a survey questioning their feelings and thoughts that were associated with specific advertisements and colors. In this method $40.8 \%$ of the participants were 33 years and older, $9.2 \%$ were from ages 28 to $32,9.9 \%$ ranged from 23 to 27 years old, and $40.1 \%$ were 18 to 22 years old. The data received from the older participants, years 28 to 33 (50\%), as compared to the data from the younger participants, years 18 to 27 (50\%). The resulting age gap allowed the researcher to gather information from subjects with varying perspectives and life experiences.

\section{Sample Population}

To receive a diverse sample, students meeting the age requirements were randomly selected with the help of the school office. Students were given time at the beginning of their class period to complete the survey. In return, students were 
offered one hour of community service credit after taking the survey and sharing it with friends in the same age group. The survey was then distributed to the school staff who represent a variety of cultural identities, such as American, Asian, Israeli, and Spanish heritages. Assuming that the adults would be cooperative, there was no incentive offered and instead, they were asked to forward the survey to friends or previous students.

\section{Procedure}

Students were offered the option to complete the survey on the researcher's computer or their own so no person could be excluded for not having the resources to participate. Subjects that were willing to participate in the study generally asked the objective of the questions being asked and were anxious to understand the researcher's hypothesis. Others that appeared hesitant to fill out the survey were given additional information about the researcher's question and eventually chose to participate. The survey began with demographic questions which led to examinations about ecigarettes and the JUUL advertisements. Then, subjects were requested to discuss their opinions about trends on social media and to rank the popularity of JUUL in their community out of 10 values (See Table 1).

Table 1

\begin{tabular}{|c|c|c|}
\hline Questions: & Measurement Scale: & Source: \\
\hline Are you enrolled in college? & Yes, No & \\
\hline What is your age? & 18-22 years, 23-27 years, 28-32 years, $33+$ years & \\
\hline $\begin{array}{l}\text { Do you know about the products } \\
\text { known as electronic cigarettes or } \\
\text { e-cigarettes? }\end{array}$ & Yes, No & Self-Defined \\
\hline Do you know what a Juul is? & Yes, No & Self-Defined \\
\hline $\begin{array}{l}\text { Are any of the advertisements } \\
\text { below familiar to you? } \\
\text { Figure 1: Juul. (2019). Juul's } \\
\text { [Adverized' launch campaign } \\
\text { http://tobacco.stanford.edu/to- } \\
\text { bacco_main/publica- } \\
\text { tions/JUUL_Marketing_Stanford. } \\
\text { pdf }\end{array}$ & Yes, No & Self-Defined \\
\hline
\end{tabular}




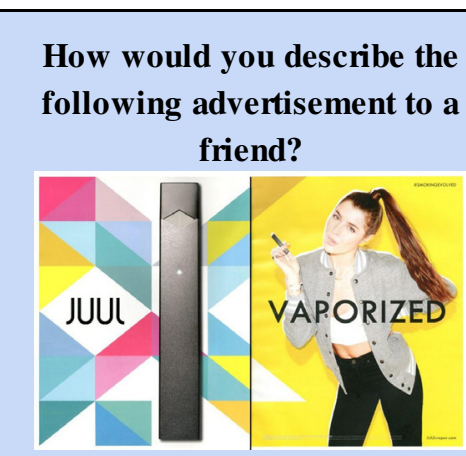

Figure 2: Juul. (2018). Juul 'Vaporized' [Advertisement]. Retrieved from

https://www.forbes.com/sites/kat hleenchaykowski/2018/11/16/thedisturbing-focus-of-juuls-earlymarketing-cam-

paigns/\#62d6216214f9

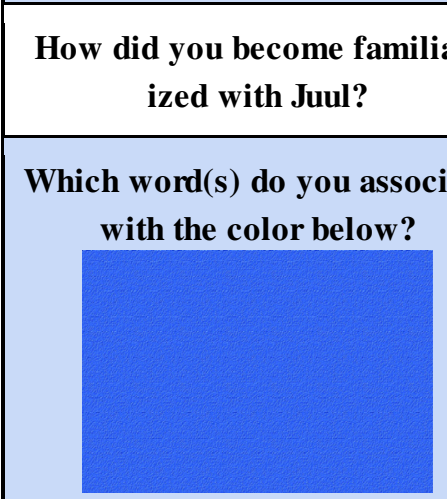

Figure 3: [Image of the color blue] (2013). Retrieved from https://www.theguardian.com/music/musicblog/2013/aug/01/readers-recommend-songs-colour-blue-results

Which word(s) do you associate with the color below?

Rebellious, Party-like, Boring, Disgusting, Happy, Cool

Self-Defined

Friends, Social media, Party, School, Family, N/A, Other:

Peace, Disgust, Anger, Calm, Maternal, Young, Old

Self-Defined

Figure 4:[Image of the color pink] (2020). Retrieved from 


\begin{tabular}{|c|c|c|}
\hline $\begin{array}{c}\text { https://www.computer- } \\
\text { hope.com/jargon/p/pink.htm }\end{array}$ & Yes, No & Self-Defined \\
\hline $\begin{array}{c}\text { Have you ever participated in a } \\
\text { trend on social media? } \\
\text { (ex: TIkTok, Mukbang, Snap- } \\
\text { chat,Fortnite, Air Force Sneak- } \\
\text { ers, etc.) }\end{array}$ & Free-Response & Self-Defined \\
\hline $\begin{array}{c}\text { Do you feel pressured to partici- } \\
\text { pate in the trends on social me- } \\
\text { dia? Why or why not? }\end{array}$ & 1=Uncommon, 10=Popular & Self-Defined \\
$\begin{array}{c}\text { Indicate on the scale of how } \\
\text { common Juuling is in your com- } \\
\text { munity. }\end{array}$ & & \\
\hline
\end{tabular}

\section{Methodology \#2}

To further prove the hypothesis, the researcher conducted a second part of the study. This section will discuss group mentality, psychological reactance, and Generation Z's thoughts on specific advertisements shown to them.

\section{Participants}

In this section of the study, 42 participants ranging from the ages of 15 to 18 years old participated in a group experiment. The subjects tended to be in the upper-middle class and attended co-ed high schools in Broward County, Florida. Students in grades 9 through 12 were grouped together and therefore, opinions were offered from people at different levels of academic rigor.

\section{Sample Population}

To test a diverse sample, students were randomly selected by the school office to be a participant in the researcher's group experiment. Because of the assumption that a majority of students would enter the high school building through the main entrance between 7:40-8:00 am, the researcher approached students outside of the main entrance to convince them to sign up at the school office. As an incentive, students were offered an hour of community service credit if they engage in the group experiment. No participants were told about the objective of the experiment to avoid skewing of the results or findings.

\section{Procedure}

After students were approached by the researcher and asked to sign up at the office, a total of 12 students decided to participate. Students who agreed were emailed the room number and time to meet and were advised to arrive eager to participate in discussions. To have a larger scale to analyze for the group experiment, the researcher reached out to teachers for assistance. After communicating the difficulties in having students volunteer, the teachers invited the researcher to their classes to conduct the research with their students. Students were offered participation points if they participated in the group and individual discussions; therefore, the total number of subjects reached 42 . 
All subjects were placed in groups that ranged between 9th and 12th grade. Each group consisted of 6 subjects. To test basic group dynamics theory, the subjects were asked an unrelated question (on gun control) both individually and in a group forum. The researcher chose the topic of gun control because of the many opinions about it which would make it easier for all participants to engage in the conversation. The goal of the researcher was to analyze whether peoples' opinions would change once shared with a group of peers. Then, they were shown three advertisements on cigarettes that contained the same motto and brand name. One of them portrayed an old man as the model with dark red in the background (see Figure 5), while the other two presented a young woman provocatively smoking a cigarette. The difference between the two advertisements was that one of them had a background with dark blue, red, and light yellow (see Figure 6), while the second one had a background with bright pink and blue (see Figure 7). The researcher edited one of the advertisements with the young woman and changed the color of the background to match those on the JUUL advertisements.

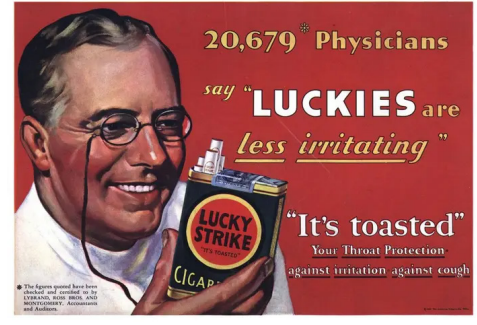

Figure 5

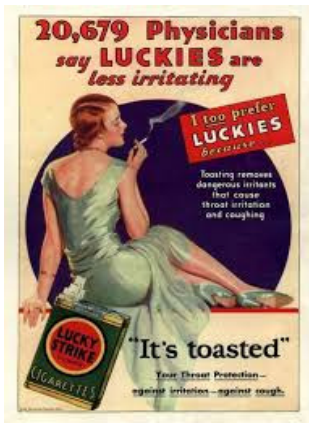

Figure 6

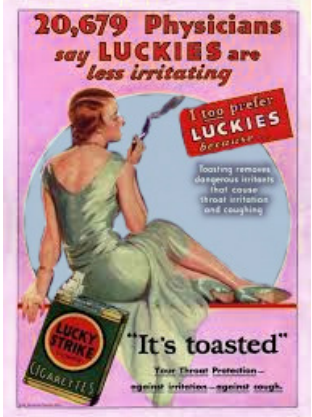

Figure 7

\begin{tabular}{|l|lr|}
\hline Figure 5: Lucky Strike. (2015). & Figure 6: Lucky Strike. (1930). \\
Luckies Cigarettes [Advertise- & Luckies Cigarettes [Advertise- \\
ment]. Retrieved from & ment]. r Retrieved from \\
https://rwoodall17.wee- & https://amhistory.si.edu/ar- \\
bly.com/blog/luckies-advertise- & chives/AC1224-0000002.pdf \\
ment & \\
\hline
\end{tabular}

The students were asked individually to decide which out of the three advertisements (See Figure 5,6,7) attracted them more to the product. Students were asked to gather in a group circle to discuss which poster they chose and their reasoning. The researcher's goal was to observe if the participant's thoughts on an advertisement changed after hearing their peers ratiocinate their own decisions. The researcher then wanted to test the psychological reactance theory by seeing whether the subjects would be more attracted to the advertisements if they were told they could not buy the product. Therefore, the researcher told the students that they were prohibited from purchasing the product shown in Figure 7, as it was the most popular, and asked for their thoughts on the posters to see if it differed from their initial opinion. Later, the students were shown advertisements from a modern cigarette company, Marlboro, (see Figure 8) compared to a modern e-cigarette company, JUUL, (see Figure 9) and were asked to discuss the similarities between both posters, judging which one is more efficient in attracting them as consumers. 


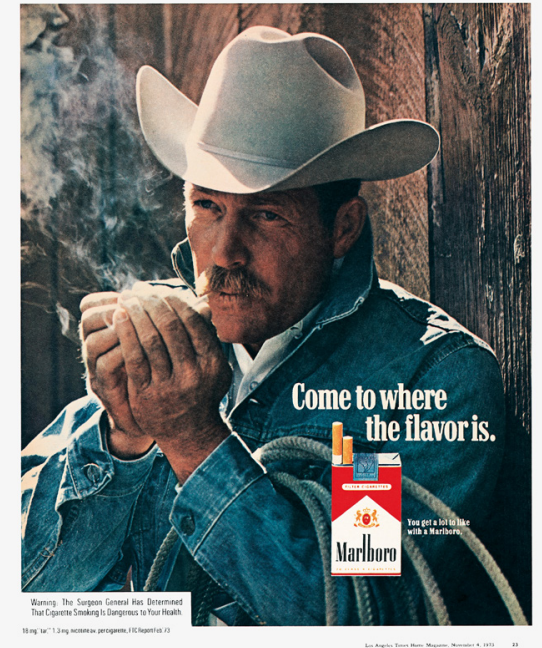

Figure 8

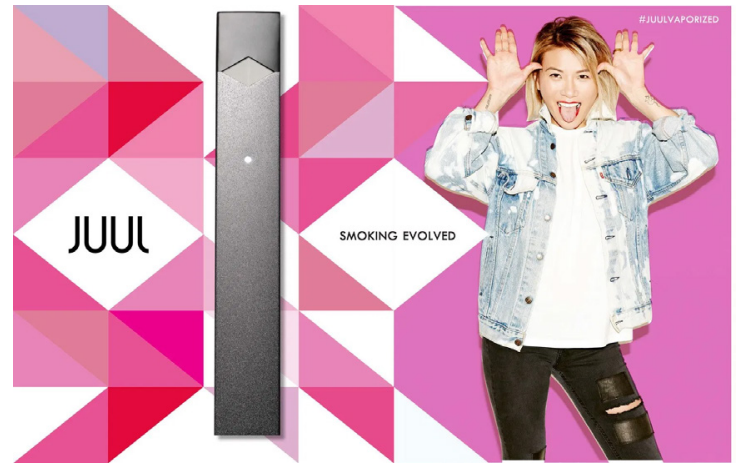

Figure 9
Figure 8: Marlboro. (2018). Marlboro Man [Advertisement]. Retrieved from https://www.cnn.com/style/article/alcohol-cigarette-vintage-ads/index.html
Figure 9: Juul. (2019). Juul 'Vaporized' [Advertisement]. Retrieved from https://truthinitiative.org/research-resources/emerging-tobaccoproducts/juul-keeps-saying-its-popularity-young-people-accident

Lastly, to continue to study herd mentality, the subjects were asked to stand in a straight line outside the classroom and walk down the hallway single file. The researcher placed an extra student at the front of the line who was asked to stop in the middle of the hallway. The goal of this activity was to determine if the students listened to the verbal directions or reacted to the actions of the group. Once all of the experiments were completed, data were collected and recorded on the researcher's computer. Afterward, the participants were informed more about the purpose and objectives of the experiments for them to understand the reasoning behind the researcher's procedure.

Even though there was data being recorded through two outlets, the survey, and group experiment, both results will work collaboratively to discuss the researcher's hypothesis and form limitations.

\section{Findings}

The results of the survey and group experiments conducted to support that most high school and college students are more attracted and familiar with the JUUL advertisements through friends, parties, and social media. The respondents who were adults supported the idea that they are familiar with e-cigarettes but have never seen the popular JUUL posters or commercials. Overall, the participants ranging from 14 years old to 33 years and older agreed that the color blue associated with the word "Calm" or "Peace," while the color pink associated with the word "Young" or "Maternal." Also, the survey revealed that participants 18 through 22 years old have participated in the trend cycle but are not aware that they continuously participate and in result, are pressured. Therefore, as seen by the opinions of teenagers, college students, and adults, reform must be implemented in order to prevent the promotion of the JUUL posters and commercials to the younger generations. 


\section{Quantitative Data}

The survey yielded results from college students and adults, all involved in different types of occupations. Out of the 152 participants, 97\% were familiarized with JUUL (Figure 10) and of that group, the majority heard about the JUUL product through social media, friends, and parties (Figure 11). Their responses will be relevant when proving the researcher's hypothesis by showing one of the company's market strategies, herd dynamics.

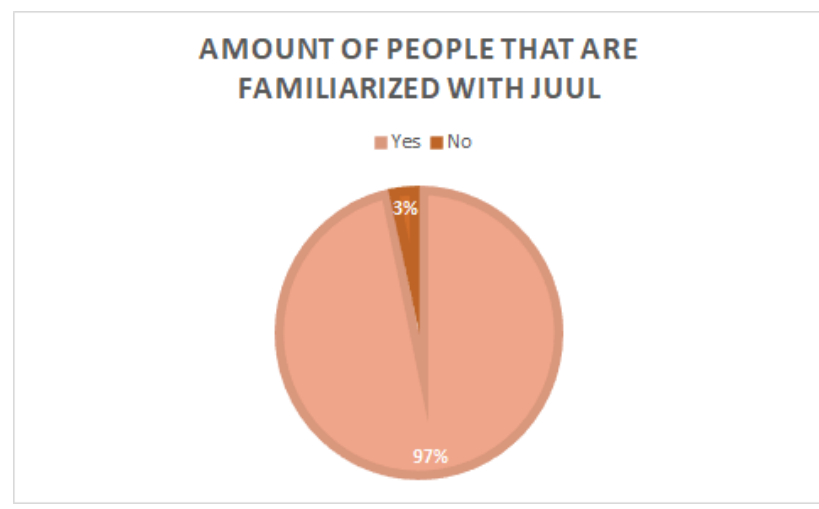

Figure 10

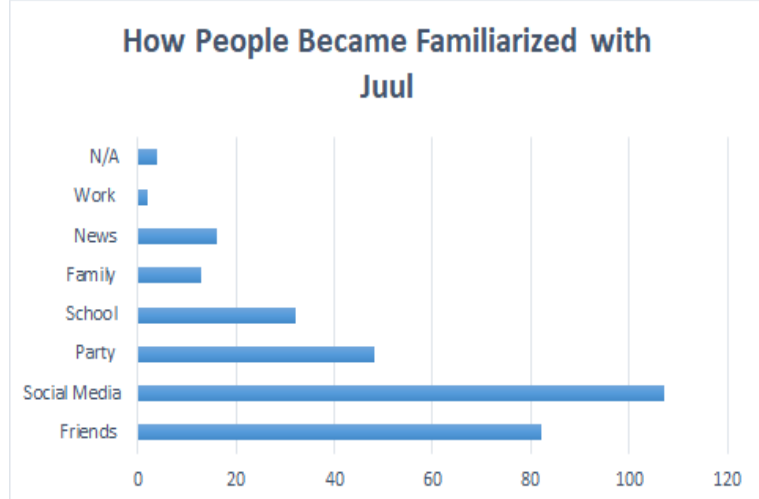

Figures 12 and 13 display data from the survey showing the respondents feelings towards the color blue and pink. The information gathered below proves the effectiveness of color-connection and the reasoning behind the colors casted on the JUUL commercials.

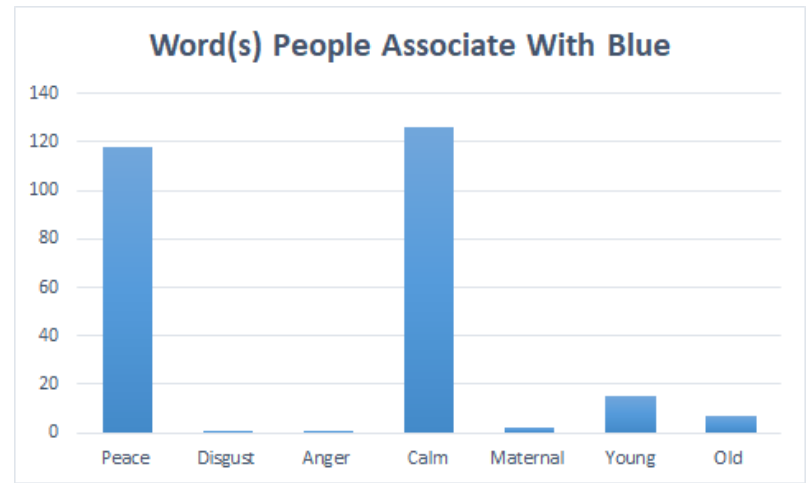

Figure 12

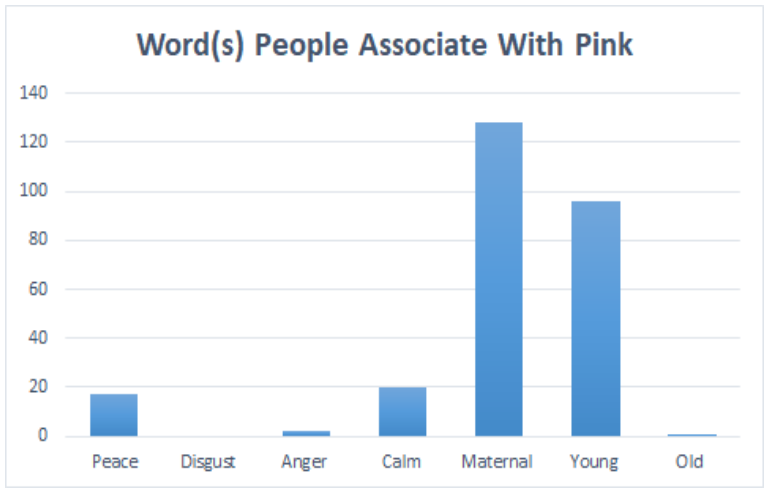

Figure 13 
To further analyze the effect of the colors shown in the advertisements, participants were asked to describe the JUUL poster (Figure 14). The data shown below supports the researcher's reasoning that the colors shown reflect a "Partylike" environment and in return, attract the younger people to vape so they can be considered "Cool" or popular.

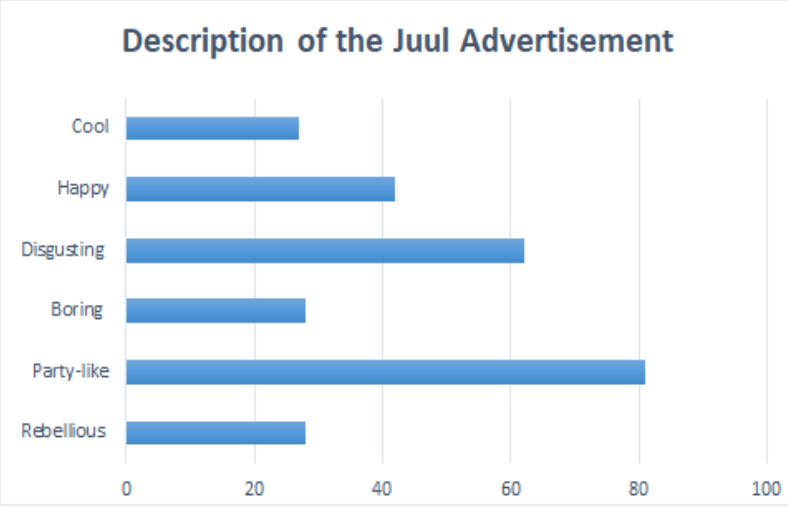

Figure 14

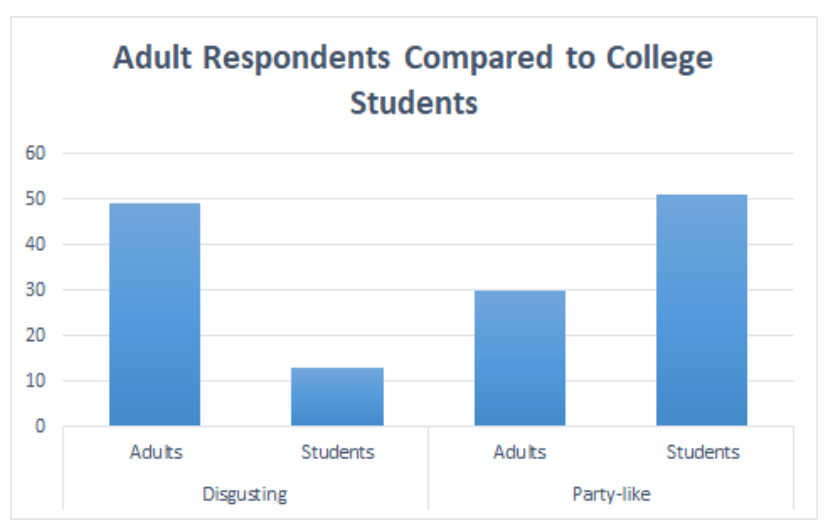

Figure 15

In order for the researcher to understand the cycle of societal trends, the survey offered two questions regarding the participants' familiarity with certain trends and if they feel pressured to participate. The results, shown in Figure 16 and 17 , reveal that the majority of subjects have participated in various trends, but do not feel pressured to do so.

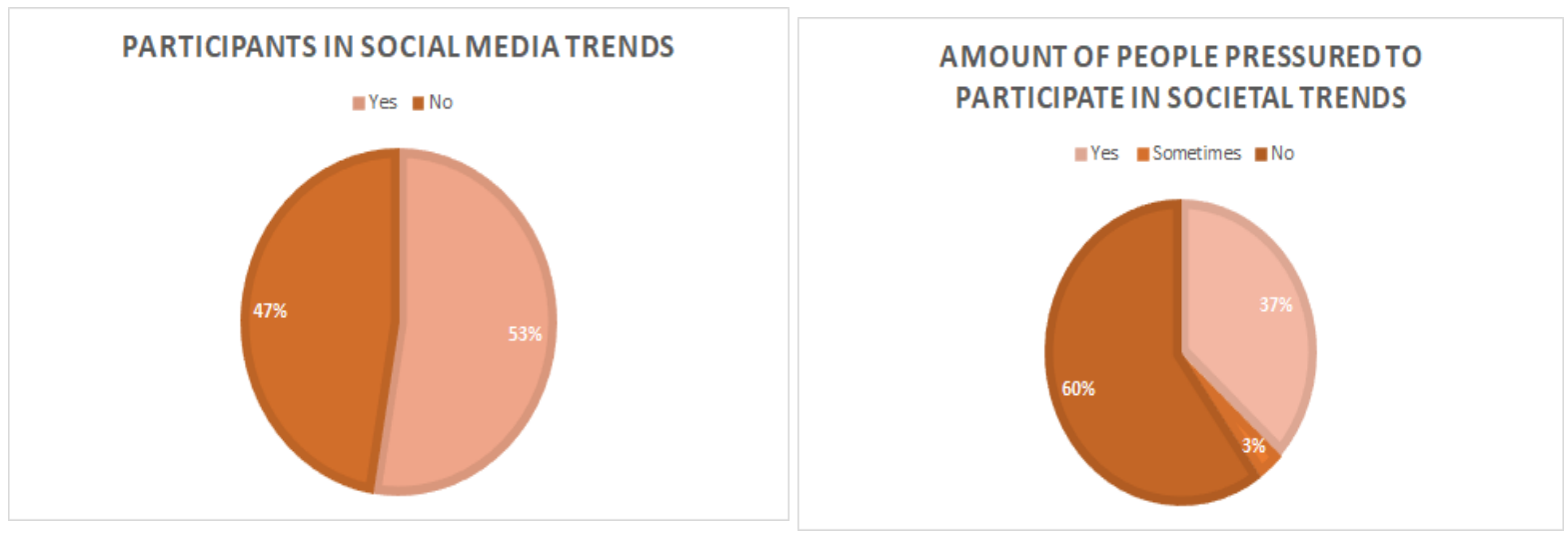

Figure 16

Figure 17

Lastly, the researcher thought it was important to gather data on the presence of JUUL in each individual's community on a scale from 1 (uncommon) to 10 (popular). The findings in Figure 18 support the major impact the JUUL product has presented in communities as a result of the companies' influential marketing techniques. 


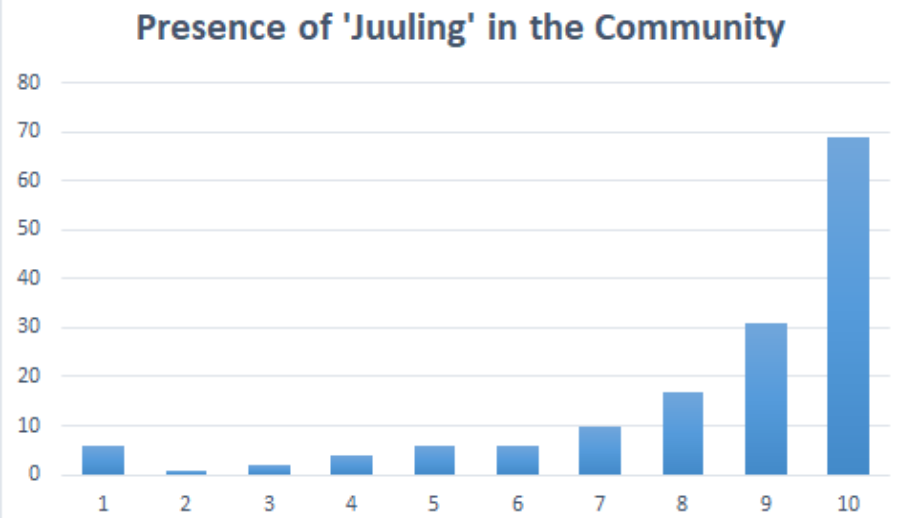

Figure 18

\section{Qualitative Data}

Although a survey was conducted, the researcher decided to also gather data from group experiments in order to study the psychological reactance theory and further prove the effectiveness of color-connection and herd mentality. In Table 2, 3, 4,5, 6, 7, 8, the results of each individual group are displayed and will be analyzed. The researcher was able to collect the information below through individual and group discussions, and then studied changes in people's opinions and decisions.

Table 2

\begin{tabular}{|c|c|c|c|c|c|c|c|}
\hline Group 1 & $\begin{array}{c}\text { Individual } \\
\text { Opinion on } \\
\text { Gun Control }\end{array}$ & $\begin{array}{l}\text { Individ- } \\
\text { ual Opin- } \\
\text { ion on } \\
\text { Ads }\end{array}$ & $\begin{array}{l}\text { Group Opin- } \\
\text { ion on Gun } \\
\text { Control }\end{array}$ & $\begin{array}{l}\text { Group } \\
\text { Opinion } \\
\text { on Ads }\end{array}$ & $\begin{array}{l}\text { Psycho- } \\
\text { logical } \\
\text { Reactance } \\
\text { Theory }\end{array}$ & $\begin{array}{l}\text { Modern Juul } \\
\text { Ad vs. Modern } \\
\text { Cigarette Ad }\end{array}$ & $\begin{array}{c}\text { Herd Dy- } \\
\text { namic } \\
\text { Theory }\end{array}$ \\
\hline $\begin{array}{c}\text { Subject } \\
1\end{array}$ & Pro- Guns & Figure 1 & $\begin{array}{l}\text { Remained the } \\
\text { same }\end{array}$ & $\begin{array}{l}\text { Remained } \\
\text { the same }\end{array}$ & $\begin{array}{c}\text { Not } \\
\text { Proven }\end{array}$ & $\begin{array}{c}\text { Modern Ciga- } \\
\text { rette Ad }\end{array}$ & Proven \\
\hline $\begin{array}{c}\text { Subject } \\
2\end{array}$ & Pro-Guns & Figure 3 & $\begin{array}{l}\text { Remained the } \\
\text { same }\end{array}$ & $\begin{array}{l}\text { Remained } \\
\text { the same }\end{array}$ & Proven & $\begin{array}{c}\text { Modern Juul } \\
\text { Ad }\end{array}$ & Proven \\
\hline $\begin{array}{c}\text { Subject } \\
3\end{array}$ & Indifferent & Figure 3 & Pro-Guns & $\begin{array}{l}\text { Remained } \\
\text { the same }\end{array}$ & Proven & $\begin{array}{l}\text { Modern Juul } \\
\text { Ad }\end{array}$ & Proven \\
\hline $\begin{array}{c}\text { Subject } \\
4\end{array}$ & Anti-Guns & Figure 3 & $\begin{array}{c}\text { Remained the } \\
\text { same }\end{array}$ & $\begin{array}{l}\text { Remained } \\
\text { the same }\end{array}$ & $\begin{array}{c}\text { Not } \\
\text { Proven }\end{array}$ & $\begin{array}{l}\text { Modern Juul } \\
\text { Ad }\end{array}$ & Proven \\
\hline $\begin{array}{c}\text { Subject } \\
5\end{array}$ & Pro-Guns & Figure 2 & $\begin{array}{c}\text { Remained the } \\
\text { same }\end{array}$ & $\begin{array}{l}\text { Remained } \\
\text { the same }\end{array}$ & $\begin{array}{c}\text { Not } \\
\text { Proven }\end{array}$ & $\begin{array}{l}\text { Modern Juul } \\
\text { Ad }\end{array}$ & Proven \\
\hline $\begin{array}{c}\text { Subject } \\
6\end{array}$ & Anti-Guns & Figure 3 & Pro-Guns & $\begin{array}{l}\text { Remained } \\
\text { the same }\end{array}$ & $\begin{array}{c}\text { Not } \\
\text { Proven }\end{array}$ & $\begin{array}{c}\text { Modern Juul } \\
\text { Ad }\end{array}$ & Proven \\
\hline
\end{tabular}


Table 3

\begin{tabular}{|c|c|c|c|c|c|c|c|}
\hline Group 2 & $\begin{array}{c}\text { Individual } \\
\text { Opinion on } \\
\text { Gun Control }\end{array}$ & $\begin{array}{l}\text { Individ- } \\
\text { ual Opin- } \\
\text { ion on } \\
\text { Ads }\end{array}$ & $\begin{array}{l}\text { Group Opinion } \\
\text { on Gun Con- } \\
\text { trol }\end{array}$ & $\begin{array}{l}\text { Group } \\
\text { Opinion } \\
\text { on Ads }\end{array}$ & $\begin{array}{c}\text { Psycho- } \\
\text { logical } \\
\text { Reactance } \\
\text { Theory }\end{array}$ & $\begin{array}{l}\text { Modern Juul Ad } \\
\text { vs. Modern Cig- } \\
\text { arette Ad }\end{array}$ & $\begin{array}{l}\text { Herd Dy- } \\
\text { namic } \\
\text { Theory }\end{array}$ \\
\hline $\begin{array}{c}\text { Subject } \\
1\end{array}$ & Pro- Guns & Figure 2 & $\begin{array}{l}\text { Remained the } \\
\text { same }\end{array}$ & $\begin{array}{c}\text { Remained } \\
\text { the same }\end{array}$ & $\begin{array}{c}\text { Not } \\
\text { Proven }\end{array}$ & Modern Juul Ad & Proven \\
\hline $\begin{array}{c}\text { Subject } \\
2\end{array}$ & Anti-Guns & Figure 3 & Pro-Guns & $\begin{array}{c}\text { Remained } \\
\text { the same }\end{array}$ & Proven & Modern Juul Ad & Proven \\
\hline $\begin{array}{c}\text { Subject } \\
3\end{array}$ & Pro-Guns & Figure 1 & $\begin{array}{l}\text { Remained the } \\
\text { same }\end{array}$ & $\begin{array}{c}\text { Remained } \\
\text { the same }\end{array}$ & Proven & $\begin{array}{l}\text { Modern Ciga- } \\
\text { rette Ad }\end{array}$ & Proven \\
\hline $\begin{array}{c}\text { Subject } \\
4\end{array}$ & Anti-Guns & Figure 3 & $\begin{array}{l}\text { Remained the } \\
\text { same }\end{array}$ & $\begin{array}{c}\text { Remained } \\
\text { the same }\end{array}$ & Proven & Modern Juul Ad & Proven \\
\hline $\begin{array}{c}\text { Subject } \\
5\end{array}$ & Anti-Guns & Figure 3 & $\begin{array}{c}\text { Remained the } \\
\text { same }\end{array}$ & $\begin{array}{c}\text { Remained } \\
\text { the same }\end{array}$ & Proven & Modern Juul Ad & Proven \\
\hline $\begin{array}{c}\text { Subject } \\
6\end{array}$ & Pro-Guns & Figure 3 & $\begin{array}{c}\text { Remained the } \\
\text { Same }\end{array}$ & $\begin{array}{c}\text { Remained } \\
\text { the same }\end{array}$ & Proven & Modern Juul Ad & Proven \\
\hline
\end{tabular}

Table 4

\begin{tabular}{|c|c|c|c|c|c|c|c|}
\hline Group 3 & $\begin{array}{l}\text { Individual } \\
\text { Opinion on } \\
\text { Gun Control }\end{array}$ & $\begin{array}{l}\text { Individ- } \\
\text { ual Opin- } \\
\text { ion on } \\
\text { Ads }\end{array}$ & $\begin{array}{l}\text { Group Opinion } \\
\text { on Gun Con- } \\
\text { trol }\end{array}$ & $\begin{array}{l}\text { Group } \\
\text { Opinion } \\
\text { on Ads }\end{array}$ & $\begin{array}{c}\text { Psycho- } \\
\text { logical } \\
\text { Reactance } \\
\text { Theory }\end{array}$ & $\begin{array}{l}\text { Modern Juul Ad } \\
\text { vs. Modern Cig- } \\
\text { arette Ad }\end{array}$ & $\begin{array}{l}\text { Herd Dy- } \\
\text { namic } \\
\text { Theory }\end{array}$ \\
\hline $\begin{array}{c}\text { Subject } \\
1\end{array}$ & Pro- Guns & Figure 3 & $\begin{array}{l}\text { Remained the } \\
\text { same }\end{array}$ & $\begin{array}{l}\text { Remained } \\
\text { the same }\end{array}$ & Proven & Modern Juul Ad & $\begin{array}{c}\text { Not } \\
\text { Proven }\end{array}$ \\
\hline $\begin{array}{c}\text { Subject } \\
2\end{array}$ & Anti-Guns & Figure 3 & Pro-Guns & $\begin{array}{l}\text { Remained } \\
\text { the same }\end{array}$ & Proven & Modern Juul Ad & Proven \\
\hline $\begin{array}{c}\text { Subject } \\
3\end{array}$ & Anti-Guns & Figure 1 & Pro-Guns & Figure 3 & $\begin{array}{c}\text { Not } \\
\text { Proven }\end{array}$ & Modern Juul Ad & Proven \\
\hline $\begin{array}{c}\text { Subject } \\
4\end{array}$ & Indifferent & Figure 1 & Pro-Guns & Figure 3 & $\begin{array}{c}\text { Not } \\
\text { Proven }\end{array}$ & Modern Juul Ad & Proven \\
\hline $\begin{array}{c}\text { Subject } \\
5\end{array}$ & Pro-Guns & Figure 1 & $\begin{array}{l}\text { Remained the } \\
\text { same }\end{array}$ & Figure 2 & $\begin{array}{c}\text { Not } \\
\text { Proven }\end{array}$ & Modern Juul Ad & Proven \\
\hline $\begin{array}{c}\text { Subject } \\
6\end{array}$ & Pro-Guns & Figure 1 & $\begin{array}{c}\text { Remained the } \\
\text { same }\end{array}$ & Figure 2 & $\begin{array}{c}\text { Not } \\
\text { Proven }\end{array}$ & Modern Juul Ad & Proven \\
\hline
\end{tabular}


Table 5

\begin{tabular}{|c|c|c|c|c|c|c|c|}
\hline Group 4 & $\begin{array}{c}\text { Individual } \\
\text { Opinion on } \\
\text { Gun Control }\end{array}$ & $\begin{array}{c}\text { Individual } \\
\text { Opinion on } \\
\text { Ads }\end{array}$ & $\begin{array}{l}\text { Group } \\
\text { Opinion on } \\
\text { Gun Con- } \\
\text { trol }\end{array}$ & $\begin{array}{c}\text { Group } \\
\text { Opinion on } \\
\text { Ads }\end{array}$ & $\begin{array}{l}\text { Psychologi- } \\
\text { cal Reac- } \\
\text { tance The- } \\
\text { ory }\end{array}$ & $\begin{array}{c}\text { Modern } \\
\text { Juul Ad vs. } \\
\text { Modern } \\
\text { Cigarette } \\
\text { Ad }\end{array}$ & $\begin{array}{l}\text { Herd Dy- } \\
\text { namic } \\
\text { Theory }\end{array}$ \\
\hline Subject 1 & Anti- Guns & Figure 1 & $\begin{array}{c}\text { Remained } \\
\text { the same }\end{array}$ & $\begin{array}{c}\text { Remained } \\
\text { the same }\end{array}$ & Proven & $\begin{array}{c}\text { Modern } \\
\text { Cigarette } \\
\text { Ad }\end{array}$ & Proven \\
\hline Subject 2 & Anti-Guns & Figure 3 & Pro-Guns & $\begin{array}{c}\text { Remained } \\
\text { the same }\end{array}$ & Proven & $\begin{array}{l}\text { Modern } \\
\text { Juul Ad }\end{array}$ & $\begin{array}{c}\text { Not } \\
\text { Proven }\end{array}$ \\
\hline Subject 3 & Pro-Guns & Figure 3 & $\begin{array}{c}\text { Remained } \\
\text { the same }\end{array}$ & $\begin{array}{c}\text { Remained } \\
\text { the same }\end{array}$ & Proven & $\begin{array}{l}\text { Modern } \\
\text { Juul Ad }\end{array}$ & Proven \\
\hline Subject 4 & Pro-Guns & Figure 3 & $\begin{array}{c}\text { Remained } \\
\text { the same }\end{array}$ & $\begin{array}{l}\text { Remained } \\
\text { the same }\end{array}$ & Proven & $\begin{array}{l}\text { Modern } \\
\text { Juul Ad }\end{array}$ & Proven \\
\hline Subject 5 & Pro-Guns & Figure 3 & $\begin{array}{c}\text { Remained } \\
\text { the same }\end{array}$ & $\begin{array}{l}\text { Remained } \\
\text { the same }\end{array}$ & Proven & $\begin{array}{l}\text { Modern } \\
\text { Juul Ad }\end{array}$ & Proven \\
\hline Subject 6 & Indifferent & Figure 1 & $\begin{array}{l}\text { Remained } \\
\text { the same }\end{array}$ & $\begin{array}{c}\text { Remained } \\
\text { the same }\end{array}$ & Proven & $\begin{array}{l}\text { Modern } \\
\text { Juul Ad }\end{array}$ & Proven \\
\hline
\end{tabular}

Table 6

\begin{tabular}{|c|c|c|c|c|c|c|c|}
\hline Group 5 & $\begin{array}{c}\text { Individual } \\
\text { Opinion on } \\
\text { Gun Control }\end{array}$ & $\begin{array}{c}\text { Individual } \\
\text { Opinion on } \\
\text { Ads }\end{array}$ & $\begin{array}{c}\text { Group } \\
\text { Opinion on } \\
\text { Gun Con- } \\
\text { trol }\end{array}$ & $\begin{array}{c}\text { Group } \\
\text { Opinion on } \\
\text { Ads }\end{array}$ & $\begin{array}{c}\text { Psychologi- } \\
\text { cal Reac- } \\
\text { tance The- } \\
\text { ory }\end{array}$ & $\begin{array}{c}\text { Modern } \\
\text { Juul Ad vs. } \\
\text { Modern } \\
\text { Cigarette } \\
\text { Ad }\end{array}$ & $\begin{array}{c}\text { Herd Dy- } \\
\text { namic } \\
\text { Theory }\end{array}$ \\
\hline Subject 1 & Pro- Guns & Figure 3 & $\begin{array}{c}\text { Remained } \\
\text { the same }\end{array}$ & $\begin{array}{c}\text { Remained } \\
\text { the same }\end{array}$ & Proven & $\begin{array}{c}\text { Modern } \\
\text { Juul Ad }\end{array}$ & Proven \\
\hline Subject 2 & Pro-Guns & Figure 1 & $\begin{array}{c}\text { Remained } \\
\text { the same } \\
\text { Remained } \\
\text { the same }\end{array}$ & Proven & $\begin{array}{c}\text { Modern } \\
\text { Juul Ad }\end{array}$ & Proven \\
\hline Subject 3 & Anti-Guns & Figure 3 & Remained & $\begin{array}{c}\text { Remained } \\
\text { the same }\end{array}$ & Proven & $\begin{array}{c}\text { Modern } \\
\text { Cigarette } \\
\text { Ad }\end{array}$ & Proven \\
\hline Subject 4 & Pro-Guns & Figure 1 & Remained & $\begin{array}{c}\text { Remained } \\
\text { the same }\end{array}$ & Proven & Modern \\
\hline
\end{tabular}




\begin{tabular}{|l|l|l|l|l|l|l|l|}
\hline & & & the same & & & Juul Ad & \\
\hline Subject 6 & Anti-Guns & Figure 2 & $\begin{array}{c}\text { Remained } \\
\text { the same }\end{array}$ & $\begin{array}{c}\text { Remained } \\
\text { the same }\end{array}$ & Proven & $\begin{array}{c}\text { Modern } \\
\text { Cigarette } \\
\text { Ad }\end{array}$ & Proven \\
\hline
\end{tabular}

Table 7

\begin{tabular}{|c|c|c|c|c|c|c|c|}
\hline Group 6 & $\begin{array}{c}\text { Individual } \\
\text { Opinion on } \\
\text { Gun Control }\end{array}$ & $\begin{array}{c}\text { Individual } \\
\text { Opinion on } \\
\text { Ads }\end{array}$ & $\begin{array}{c}\text { Group } \\
\text { Opinion on } \\
\text { Gun Con- } \\
\text { trol }\end{array}$ & $\begin{array}{c}\text { Group } \\
\text { Opinion on } \\
\text { Ads }\end{array}$ & $\begin{array}{l}\text { Psychologi- } \\
\text { cal Reac- } \\
\text { tance The- } \\
\text { ory }\end{array}$ & $\begin{array}{c}\text { Modern } \\
\text { Juul Ad vs. } \\
\text { Modern } \\
\text { Cigarette } \\
\text { Ad }\end{array}$ & $\begin{array}{c}\text { Herd Dy- } \\
\text { namic } \\
\text { Theory }\end{array}$ \\
\hline Subject 1 & Anti- Guns & Figure 3 & $\begin{array}{c}\text { Remained } \\
\text { the same }\end{array}$ & $\begin{array}{c}\text { Remained } \\
\text { the same }\end{array}$ & Proven & $\begin{array}{c}\text { Modern } \\
\text { Cigarette } \\
\text { Ad }\end{array}$ & Proven \\
\hline Subject 2 & Pro-Guns & Figure 3 & $\begin{array}{c}\text { Remained } \\
\text { the same }\end{array}$ & $\begin{array}{l}\text { Remained } \\
\text { the same }\end{array}$ & Proven & $\begin{array}{c}\text { Modern } \\
\text { Cigarette } \\
\text { Ad }\end{array}$ & Proven \\
\hline Subject 3 & Pro-Guns & Figure 1 & $\begin{array}{c}\text { Remained } \\
\text { the same }\end{array}$ & $\begin{array}{c}\text { Remained } \\
\text { the same }\end{array}$ & Proven & $\begin{array}{l}\text { Modern } \\
\text { Juul Ad }\end{array}$ & Proven \\
\hline Subject 4 & Anti-Guns & Figure 1 & $\begin{array}{l}\text { Remained } \\
\text { the same }\end{array}$ & $\begin{array}{l}\text { Remained } \\
\text { the same }\end{array}$ & Proven & $\begin{array}{l}\text { Modern } \\
\text { Juul Ad }\end{array}$ & Proven \\
\hline Subject 5 & Anti-Guns & Figure 1 & Indifferent & Figure 3 & Not Proven & $\begin{array}{l}\text { Modern } \\
\text { Juul Ad }\end{array}$ & Proven \\
\hline Subject 6 & Pro-Guns & Figure 3 & $\begin{array}{l}\text { Remained } \\
\text { the same }\end{array}$ & $\begin{array}{c}\text { Remained } \\
\text { the same }\end{array}$ & Proven & $\begin{array}{c}\text { Modern } \\
\text { Cigarette } \\
\text { Ad }\end{array}$ & Proven \\
\hline
\end{tabular}


Table 8

\begin{tabular}{|c|c|c|c|c|c|c|c|}
\hline Group 7 & $\begin{array}{c}\text { Individual } \\
\text { Opinion on } \\
\text { Gun Control }\end{array}$ & $\begin{array}{c}\text { Individual } \\
\text { Opinion on } \\
\text { Ads }\end{array}$ & $\begin{array}{c}\text { Group } \\
\text { Opinion on } \\
\text { Gun Con- } \\
\text { trol }\end{array}$ & $\begin{array}{c}\text { Group } \\
\text { Opinion on } \\
\text { Ads }\end{array}$ & $\begin{array}{l}\text { Psychologi- } \\
\text { cal Reac- } \\
\text { tance The- } \\
\text { ory }\end{array}$ & $\begin{array}{c}\text { Modern } \\
\text { Juul Ad vs. } \\
\text { Modern } \\
\text { Cigarette } \\
\text { Ad }\end{array}$ & $\begin{array}{c}\text { Herd Dy- } \\
\text { namic } \\
\text { Theory }\end{array}$ \\
\hline Subject 1 & Pro- Guns & Figure 3 & $\begin{array}{l}\text { Remained } \\
\text { the same }\end{array}$ & $\begin{array}{l}\text { Remained } \\
\text { the same }\end{array}$ & Proven & $\begin{array}{l}\text { Modern } \\
\text { Juul Ad }\end{array}$ & Proven \\
\hline Subject 2 & Pro-Guns & Figure 1 & $\begin{array}{l}\text { Remained } \\
\text { the same }\end{array}$ & $\begin{array}{l}\text { Remained } \\
\text { the same }\end{array}$ & Proven & $\begin{array}{l}\text { Modern } \\
\text { Cigarette } \\
\text { Ad }\end{array}$ & $\begin{array}{c}\text { Not } \\
\text { Proven }\end{array}$ \\
\hline Subject 3 & Pro-Guns & Figure 2 & $\begin{array}{l}\text { Remained } \\
\text { the same }\end{array}$ & Figure 3 & Not Proven & $\begin{array}{l}\text { Modern } \\
\text { Juul Ad }\end{array}$ & Proven \\
\hline Subject 4 & Anti-Guns & Figure 3 & Pro-Guns & $\begin{array}{l}\text { Remained } \\
\text { the same }\end{array}$ & Proven & $\begin{array}{l}\text { Modern } \\
\text { Juul Ad }\end{array}$ & Proven \\
\hline Subject 5 & Anti-Guns & Figure 3 & $\begin{array}{l}\text { Remained } \\
\text { the same }\end{array}$ & $\begin{array}{l}\text { Remained } \\
\text { the same }\end{array}$ & Proven & $\begin{array}{l}\text { Modern } \\
\text { Juul Ad }\end{array}$ & Proven \\
\hline Subject 6 & Anti-Guns & Figure 1 & Pro-Guns & Figure 3 & Proven & $\begin{array}{c}\text { Modern } \\
\text { Cigarette } \\
\text { Ad }\end{array}$ & Proven \\
\hline
\end{tabular}

\section{Discussion}

The results shown in Figure 12 and 13 support the researcher's hypothesis that the hues of blue and pink are casted on the screen of the JUUL commercials to gain the consumer's trust and display the product as more reliable because of the impressions the colors display, such as: Maternal, Young, Peace, and Calm. The results in the survey paralleled the group experiments as the majority of participants favored the advertisements with the colors pink and blue. However, the researcher's initial theory about the advertisements that display youthful women was disproved because not all of the participants were intrigued with the advertisement. Figure 15 shows the difference of opinions on the advertisements between adults and college students. Majority of adults described the advertisement as "Disgusting" and "Boring" (79\%), while college students found the advertisement to be "Party-like" and "Cool" (62\%). The results from the survey for the college students align with the group experiment, as the high school participants were also attracted to the advertisements with pictures or drawings of young-looking women.This reveals a pattern that the younger the participants are, the more likely they will enjoy advertisements that demonstrate appealing drawings or pictures of women.

Also, the researcher's expectations for the theory of Psychological Reactance was overall proven in the group experiment because most teenagers $(73 \%)$ were attracted to the advertisement (see Figure 7 ) once told that they could not buy the product. Consequently, the laws implemented to restrict the supply of JUUL, along with the movements that advertise the dangers of vaping, cause the younger generations to be fascinated with the JUUL products as a result of psychological reactance. Therefore, the solutions currently put into practice need reform and modifications. Ac- 
cording to a study published by the Journal of Health Psychology, an effective tactic to prevent psychological reactance is to focus on the positive changes instead of making the person feel as if they have lost something (Cho, Sands, Hwang, \& Jeong, 2012). Future prevention-advertisements and laws must present the benefits of rejecting smoking or vaping, and avoid using the words, "phrases" or "quitting".

Throughout the experiments, the researcher's hypotheses about herd mentality were supported by the participants (95\%) continuously deciding to copy each other's behavior. The results of the survey in Figure 11 display that the majority of the subjects recognized the JUUL product from social media, parties, or friends which shows that the popularity of the product grew through an echo chamber. According to Oxford Dictionary, an echo chamber is, "an environment in which somebody encounters only opinions and beliefs similar to their own, and does not have to consider alternatives"(Echo chamber, 2019). Because vaping is so glamorized amongst teens, the young adults will enter a social media echo chamber when they try to search information on JUUL and the consequences of vaping. Then, teenagers will receive misinformation and will be enticed to follow the ongoing vape trend displayed on their social media feed; as a result, the teens would be creating an echo chamber amongst themselves by promoting the JUUL product to their friends which inevitably will help the increase in youth JUUL consumption. In Figure 16 and 17, which show the findings from the survey, most subjects said that they have participated in societal trends but then continue to state that they have never been pressured to follow the trends. This also poses as an example of a social media echo chamber because people do not realize they are falling into the trend cycle since the trends, such as vaping, continue to consume their internet feed.

The researcher's theory was continued to be proven in the group experiments because each participant followed the actions of the person in front of them, despite the directions given to them by the researcher. However, even though some subjects did change their opinions during the group discussions, the majority continued to support their initial thoughts against others. This contradicts the researcher's assumption that a large number of participants would change their opinion to fit in with the others in the group. Therefore, the practices to further advertise the JUUL product, such as: color-connection, psychological reactance, and group mentality are all proven to be effective throughout the course of this research paper.

\section{Limitations}

There are limitations presented in the researcher's study. This study lacked a broad sample of students in order to analyze the extent of practices used by modern companies such as JUUL. All high school student participants attend schools within the upper-middle class community in Broward, Florida that host yearly anti-smoking seminars and have anti-vaping campaigns a part of their health curriculum. Therefore, the researcher was not able to examine whether these economical and educational factors had an effect on the student's opinions about the JUUL products and advertisements. Also, the college student participants attend universities in Florida; therefore the location may play a role in their views about JUUL. Lastly, the researcher focused on one popular company instead of breaking down and studying the insidious practices of various companies. For future research on this topic, the researcher suggests to gather a more diverse sample section and to take into consideration outside factors that may affect the person's opinions on vaping.

\section{Conclusion}

While other studies have researched the influence of JUUL's advertisement on adults and have examined the increase of sales for the company, the information gathered by the results of this research paper have impacted the advertising field by demonstrating the effectiveness of the marketing practice on teenagers and young adults through analyzing the JUUL companies' advertising techniques. After considering the findings of this paper, companies must understand the power of advertising to teenagers and must use practices focused on the appropriate age for the product. As a 
future solution, corporate lobbying in government for JUUL must be further restricted. According to the Center for Responsive Politics, a platform that allows users to follow the connections between money and lobbying, the total spending for lobbyists was 3.5 billion dollars in the year of 2019 (Influence \& Lobbying, 2020). In order to prevent the widespread distribution of the JUUL advertisements, lobbying in government for the company must be minimal and therefore, the company will not gain power in numbers. As a result, teenagers will not be as exposed to JUUL's marketing and there will be a decrease of death rates caused by vaping. A subsequent stage would be for companies to distribute advertisements presenting the benefits of rejecting vaping instead of the negatives. Also, to encourage people to research topics from an objective view and discover different perspectives on subjects in order to prevent falling into a social media echo chamber. Overall, this study brings a new light to the widespread problem of youth vaping by explaining how the advertising aspect of JUUL plays a bigger role than expected.

\section{Acknowledgements}

I would like to express my gratitude to Ms. Mindicino, my research supervisor, for her continuous encouragement and guidance. Her valuable criticism allowed me to develop my research work and has been very much appreciated. I would also like to thank my mother for her ongoing support throughout my study.

\section{Bibliography}

Abbot, B. (2019). New York Identifies Vitamin E Oil in Vaping Samples. The Wall Street Journal

Aslam, M. (2006). Are You Selling the Right Colour? A Cross-Cultural Review of Colour as a Marketing Cue. Journal of Marketing Communications.

Barshad, A. (2018). The Juul Is Too Cool . The New York Times .

Belluz, J. (2019, January 25). The vape company Juul said it doesn't target teens. Its early ads tell a different story. Retrieved from Vox : https://www.vox.com/2019/1/25/18194953/vape-juul-e-cigarette-marketing

Boseley, S. (2015). Hon Lik invented the e-cigarette to quit smoking - but now he's a dual user. The Gaurdian .

Brehm, J. W. (1966). A theory of psychological reactance. Academic Press.

Cherry, K. (2019, November 15). The Color Psychology of Pink: How Does Pink Make You Feel?

Cho, H., Sands, L., Hwang, Y., \& Jeong, S. (2012). Effects of gain- and loss-framed messages on the sun safety behavior of adolescents: the moderating role of risk perceptions. Journal of Health Psychology.

Cunningham, M. K. (2017). The Value of Color Research in Brand Strategy. Open Journal of Social Sciences.

Czaplicki, L., Kostygina, G., Kim, Y., Perks, S., Szczypka, G., Emery, S., . . Hair, E. (2019). Characterising JUULrelated posts on Instagram. British Medical Journal.

Desilver, D. (2019). The concerns and challenges of being a U.S. teen: What the data show. Pew Research Center .

Ducharme, J. (2019). Is Vaping Marijuana Safe? Deaths and Lung Disease Linked to E-Cigs Call That Into Question. TIME. 
Echo chamber. (2019). Retrieved from Oxford Online Dictionary : https://www.oxfordlearnersdictionaries.com/us/definition/english/echo-chamber

Fehre, C. (2014 , November 21). A brief history of the e-cigarette. Retrieved from OUPblog : https://blog.oup.com/2014/11/e-cigarette-vape-timeline/

Figure 1: Juul. (2019). Juul's 'Vaporized' launch campaign [Advertisement]. Retrieved from http://tobacco.stanford.edu/tobacco_main/publications/JUUL_Marketing_Stanford.pdf

Figure 2: Juul. (2018). Juul 'Vaporized' [Advertisement]. Retrieved from https://www.forbes.com/sites/kathleenchaykowski/2018/11/16/the-disturbing-focus-of-juuls-early-marketing-campaigns/\#62d6216214f9

Figure 3: [Image of the color blue] (2013). Retrieved from https://www.theguardian.com/music/musicblog/2013/aug/01/readers-recommend-songs-colour-blue-results

Figure 4: [Image of the color pink] (2020). Retrieved from https://www.computerhope.com/jargon/p/pink.htm

Figure 5: Lucky Strike. (2015). Luckies Cigarettes [Advertisement]. Retrieved from https://rwoodall17.weebly.com/blog/luckies-advertisement

Figure 6: Lucky Strike. (1930). Luckies Cigarettes [Advertisement]. Retreived from https://amhistory.si.edu/archives/AC1224-0000002.pdf

Figure 8: Marlboro. (2018). Marlboro Man [Advertisement]. Retrieved from https://www.cnn.com/style/article/alcohol-cigarette-vintage-ads/index.html

Figure 9: Juul. (2019). Juul 'Vaporized' [Advertisement]. Retrieved from https://truthinitiative.org/research-resources/emerging-tobacco-products/juul-keeps-saying-its-popularity-young-people-accident

Gentzke, A. S., Creamer , M., Cullen, K. A., Ambrose, B. K., Willis, G., Jamal, A., \& King, B. A. (2019). Vital Signs: Tobacco Product Use Among Middle and High School Students — United States, 2011-2018. Morbidity and Mortality Weekly Report, 157-164.

Haller, K. (2011, March 30). Blog: Branding - why red \& yellow is used by the fast food industry. Retrieved from Karen Haller Colour \& Design Consultancy : https://www.karenhaller.co.uk/blog/branding-why-red-yellow-is-usedby-the-fast-food-industry/

Herd mentality: Are we programmed to make bad decisions? (2019, November 21). ScienceDaily.

Huang, J., Kornfield, R., \& Emery, S. (2016). 100 Million Views of Electronic Cigarette YouTube Videos and Counting: Quantification, Content Evaluation, and Engagement Levels of Videos. Journal of Medical Internet Research.

Influence \& Lobbying . (2020, April 22). Retrieved from Open Secrets: https://www.opensecrets.org/federal-lobbying/summary 
Juul Labs Launches Advertising Campaign Aimed At Raising Awareness And Combating Underage Use. (2018, June 6). Retrieved from Juul: https://newsroom.juul.com/advertising-campaign-combating-underage-use/

Kosecki, D., \& Brown, S. (2019, September 20). Vaping: The deaths, illnesses and controversies in the last year. Retrieved from CNET : https://www.cnet.com/news/a-timeline-of-recent-juul-and-vaping-health-controversiesdeath-update/

Koval, R. (2018, May 29). Where are kids getting JUUL? Retrieved from Truth Initiative :https://truthinitiative.org/research-resources/emerging-tobacco-products/where-are-kids-getting-juul

Leung, C. H., \& Chan, W. Y. (2018). An Empirical Study on Reverse Psychology Applied in Advertising Messages. Asian Journal of Empirical Research, 321-329.

Neal, M. (2014, June 17). There Are Now 7,700 Flavors and 460 Brands of E-Cigarettes. Retrieved from Vice : https://www.vice.com/en us/article/wnjxjx/there-are-now-7700-flavors-and-460-brands-of-e-cigarettes

Pancare, R. (2018). How Do Bright Colors Appeal to Kids? SCIENCING.

Pitofsky, M. (2018). Millions of teens are vaping every day. Here's what they have to say about the growing trend. USA Today .

Richtel, M., \& Kaplan, S. (2018). Did Jull Lure Teenagers and Get 'Customers for Life'? . The New York Times .

Shlack, A., \& Albright, T. D. (2007 ). Remembering Visual Motion: Neural Correlates of Associative Plasticity and Motion Recall in Cortical Area MT. Neuron .

Stein, R. (2018). Surgeon General Warns Youth Vaping Is Now An 'Epidemic'. NPR.

The Real Cost Campaign . (2019 ). Retrieved from U.S Food \& Drug Administration : https://www.fda.gov/tobaccoproducts/public-health-education/real-cost-campaign

Warner, C. (2017, April 5). 19 Little Ways To Avoid The Social Media Echo Chamber. Bustle . 